\title{
READING DISORDERS AND DYSLEXIA IN THE PROCESS OF READING SKILLS ACQUISITION
}

\author{
Marite Rozenfelde \\ Rezekne Academy of Technologies, Latvia \\ Regina Ogrina \\ Rezekne Academy of Technologies, Latvia \\ Daniela Boneva \\ Sdruzhenie Asociacia Dyslexia, Bulgaria
}

\begin{abstract}
The paper describes research on the situation in the primary education classrooms of Latvian educational institutions regarding the detection and correction of reading disorders and dyslexia in the framework of the Erasmus + K2 project "Dyslexia Assessment Protocol (DAP)" (2019-1-LV01-KA201-060355). The results of research showed that the behaviour of primary school teachers in situations, when reading disorders are identified, varies, but most of the correction work and support in educational institutions is provided by the speech therapist. It is important to carry out the professional development of primary school teachers by providing an understanding of the terms "reading disorders" and "dyslexia", knowledge of further actions in reading disorders and dyslexia cases, support opportunities for pupils and parents, as well as collaboration with a speech therapist. Teachers recognize the need for a common methodological material for native language teachers for work with children with reading disorders or dyslexia in order to ensure that teachers, regardless of professional experience or knowledge, work as homogeneous as possible. It would also serve as a good argument for talking to pupils' parents.
\end{abstract}

Keywords: reading disorders, dyslexia.

\section{Introduction}

The globalization processes and technological developments of the 21st century are affecting the demands for education. Increasing amount of information, national education standard requirements, curricula and subject programs, and intensive learning process cause some difficulties for some children (Hodge, 2000; Christo, Davis, \& Brock, 2009; Tūbele, et al., 2013).

International reading literacy studies, organized by the International Association for the Evaluation of Educational Achievements (IEA) and the Organization for Economic Cooperation and Development (OECD) since 1991, show that pupils' reading literacy, which is essential for academic achievement, is significantly reduced in the Member States (Kauliņa \& Tūbele, 2012, 10). According to the results of OECD PISA 2018, the average reading achievement 
of Latvian pupils is slightly lower than the average results in the states of the Organization for Economic Cooperation and Development (OECD), and the pupils' achievement in reading competence has decreased by nine points compared to the previous study (Petrova \& Ozola-Balode, 2019).

Teachers believe that one of the most important skills and competences that any pupil/young person should acquire is reading, which ensures successful language development. Well-acquired reading skills facilitate the successful use of pupils' collaboration, communication and other skills in everyday life. The ability to read and understand written text has a significant impact on the quality of life, as reading efficiency provides optimal learning conditions (Gurung \& Schwartz, 2009), reading improves and develops person's memory, attention, thinking, and other psychic processes (Anspoka, 2008).

In practice, teachers often face a problem in educational institutions: pupils have reading skills' acquisition disorders. Alongside the concept of 'reading disorders', another term is used, called 'dyslexia', which results from parents 'and teachers' lack of understanding of the second concept and the inability to understand the differences between the two terms. Signs of reading disorders are the following: inability to perform word analysis and synthesis of words (individual letters are inserted or omitted); specific letter substitution and word structure distortion; repetition and omission of words, and reading of words that are not in the text; replacing one word with another; inadequate reading pace and level of understanding of the read text (Tūbele, 2008). Basically, the LMST and DIBELS Next test, which was renamed ERLITS - the Early Reading Literacy Indicator Test System [in Latvian: ALAR - agrīnās lasītprasmes attīstības rādītāju pārbaudes sistēma] - in 2018, are used to determine reading and writing difficulties in Latvia. The test does not indicate dyslexia, but it does determine how specific this restriction is.

When defining dyslexia, it should be taken in account that this condition can mean much more than reading difficulties (Buksa, 2016), as decoding exercises and syllable counting in a word are extremely difficult tasks for children with dyslexia (Tūbele, 2008.). Many authors (Marshall, 2005; 2013; Barquero, Davis \& Cutting, 2014; Molfese et al, 2010) associate dyslexia with brain dysfunction.

Professor S. Tubele made the most important contribution to the diagnosis and correction of reading disorders and dyslexia in Latvia (Tūbele, 2008, Kaulina \& Tūbele, 2012). There is also Latvian Dyslexia Society operating in the country, whose main activities are non-formal education and civic engagement of young people and protection of the interests of people with dyslexia, achieving a favourable legal framework for education and provision of quality education services (Birzniece, 2019). 


\section{Theoretical background of the problem}

Starting with the 1970s and 80s, reading literacy is considered to be the basis of formal education as the skill that a pupil needs to succeed in school. At the same time, with the development of cognitive psychology and cognitive learning theory, it has been shown that basic skills necessary for reading are not innate and, in addition to physiological processes, the development of reading skills also focuses on the cognitive processes that occur during reading and comprehension of the text being read, and how a pupil's prior knowledge affects the perception and comprehension of the read material (Alexander \& Fox, 2004). Reading literacy refers to the transcoding of the graphic form of a word into a sound form, determined by physiological and psychological processes (Graff, 2008). The ability to read and understand written text has a significant impact on quality of life, as reading efficiency provides optimal learning conditions (Gurung \& Schwartz, 2009).

Dyslexia can delay the acquisition of reading skills, but it should be taken into account that the process of correction work is more successful for children than adults (Marshall, 2019/a; Marshall, 2019/b; Torgesen, 2005), therefore, it is important to identify the problem and take corrective action as early as possible to reduce the negative impact on the learning process (Christo, Davis, \& Brock, 2009; Graham, 2012; Hodge, 2000), improve the quality of life (Gurung \& Schwartz, 2009; Nunes \& Bryant, 2009), and make reading fun for children. The limitation of achievement ability in reading and writing also affects the understanding of mathematical tasks. Some authors associate dyslexia with language disorders that impede the development of phonological understanding, and thus the development of reading skills (Sprenger - Charolles, 2013).

In school practice, native language teachers of primary schools face cases in their daily work, when they are confronted with inadequate parents' arrangements for teaching in native language classes due to a pupil's language disorder dyslexia. Parents insist on dyslexia for no valid reason, but there is no valid argument to talk to parents about dyslexia and related pedagogical activities. Teachers do not have a pedagogical tool to identify cases where a pupil has a language disorder - dyslexia, which requires further medical and speech therapy diagnosis and appropriate corrective work. It is possible to improve a pupil's learning achievements and reading-writing skills by identifying the presence of dyslexia pedagogically, additionally diagnosing dyslexia medically and approving by speech therapists, offering individualized support measures to a pupil in the further learning process, and providing individualized speech therapist's help. This theme is also topical for primary school teachers in Latvia, because not all schools have speech therapists and speech therapy diagnostics and explanatory work with teachers and parents have not taken place. There is also a 
statement in the school environment that teachers themselves do not all understand the concepts of reading disorder and dyslexia, and teachers lack knowledge of correction work opportunities and further actions in the cases of such disorders.

One of the activities of Rezekne Academy of Technologies in the ESF ERASMUS + K2 project "Dyslexia Assessment Protocol (DAP)" (2019-1-LV01KA201-060355) is to carry out research on the situation in Latvia in the aspect of detection and correction of reading disorders and dyslexia.

Research objective: to conduct an empirical study on primary school teacher's understanding of the concept of dyslexia and reading disorders, their nature, and necessary further action.

Research methods: questionnaire (Ievads pētniecībā: stratēǵijas, dizaini, metodes, 2011, 157-163; Geske \& Grīnfelds, 2001, 113-121), statistical processing of data, content analysis (for qualitative data processing) (Kroplijs \& Raščevska, 2004, 121).

\section{The research results}

Research involved primary school teachers $(n=47)$ in the age of 25 to 62 years of general education institutions of different regions, who took part in teacher professional development courses and whose classes include pupils with reading disorders.

The questionnaire contained the following questions: identification of the person as a representative of the target group and description of its activities; questions that determine the respondent's attitude, understanding of concepts, and understanding of further action in terms of reading disorders and dyslexia.

34 of all the teachers surveyed believe that a teacher may notice the probability of reading disorders at the beginning of Form 1, while 13 teachers believe that only at the end of Form 1 one can understand whether a pupil will have reading disorders. 35 teachers know and use tools that help identifying reading difficulties, but 12 teachers do not know or use anything.

When asked if they think there is a system in Latvia that identifies the risk of dyslexia, 2 teachers answer affirmatively, 15 teachers deny, but 30 teachers do not know, what the reality in the country is. 13 teachers say that there is no practice in their institution to detect the risk of dyslexia, 34 teachers claim that there is such practice in their educational institution. When asked about parents' response to a dyslexic risk assessment, teachers respond as follows: parents immediately agree ( 6 answers), parents decide to wait ( 24 answers), and parents refuse to accept the idea that their child has difficulties (17 answers).

The summary of the teachers' responses ("Agree", "Disagree”) to the statements made demonstrates teachers' understanding of dyslexia (see Table 1). 
Table 1 Primary teachers' responses to the statements

\begin{tabular}{|c|c|c|c|}
\hline No. & Statement & $\begin{array}{l}\text { Agree } \\
\text { (number of } \\
\text { answers) }\end{array}$ & $\begin{array}{l}\text { Disagree } \\
\text { (number of } \\
\text { answers) }\end{array}$ \\
\hline 1. & Dyslexia means that a person has a lower IQ. & 5 & 42 \\
\hline 2. & $\begin{array}{l}\text { Children at risk for dyslexia are lazier and/or have } \\
\text { difficulty concentrating. }\end{array}$ & 32 & 15 \\
\hline 3. & $\begin{array}{l}\text { Children at risk for dyslexia have a worse memory than } \\
\text { others. }\end{array}$ & 32 & 15 \\
\hline 4. & $\begin{array}{l}\text { Children at risk for dyslexia usually have delayed } \\
\text { speech development. }\end{array}$ & 45 & 2 \\
\hline 5. & $\begin{array}{l}\text { Children at risk for dyslexia find it difficult to follow } \\
\text { the instructions and follow the rules (even during play } \\
\text { time). }\end{array}$ & 38 & 9 \\
\hline 6. & Detection of dyslexia is the responsibility of the doctor. & 27 & 18 \\
\hline 7. & $\begin{array}{l}\text { Dyslexia can be diagnosed before a child starts } \\
\text { attending school. }\end{array}$ & 34 & 13 \\
\hline 8. & $\begin{array}{l}\text { Children at risk for dyslexia can perform most tasks } \\
\text { successfully, but they need more guidance and/or time. }\end{array}$ & 45 & 2 \\
\hline 9. & $\begin{array}{l}\text { Children at risk for dyslexia need special attention and } \\
\text { support. }\end{array}$ & 46 & 1 \\
\hline 10. & $\begin{array}{l}\text { Children at risk for dyslexia can be taught to read and } \\
\text { write. }\end{array}$ & 26 & 21 \\
\hline
\end{tabular}

Only one of the teachers surveyed claims to be knowledgeable enough to recognize and support pupils at risk for dyslexia. 42 teachers think that their knowledge is insufficient, but 4 teachers think that they do not know anything.

According the teachers' opinion, a summary of possible learning difficulties experienced by pupils at risk for dyslexia (multiple answers were possible) is shown in Table 2.

Table 2 Summary of teachers' responses to the difficulties in the learning process of pupils at risk for dyslexia

\begin{tabular}{|l|l|c|}
\hline No. & \multicolumn{1}{|c|}{ Statements } & $\begin{array}{c}\text { Number of } \\
\text { answers }\end{array}$ \\
\hline 1. & Difficulties in scheduling & 16 \\
\hline 2. & Difficulties in putting things in place & 15 \\
\hline 3. & Expression of thoughts both orally and in writing & 31 \\
\hline 4. & $\begin{array}{l}\text { A child understands oral questions and instructions, but } \\
\text { understanding of such information in a written form is difficult }\end{array}$ & 35 \\
\hline 5. & Difficulties in writing dictations & 46 \\
\hline 6. & Distraction & 24 \\
\hline
\end{tabular}




\begin{tabular}{|l|l|c|}
\hline 7. & $\begin{array}{l}\text { Visual coordination of motor movements (cutting, painting, } \\
\text { handwriting, etc.) }\end{array}$ & 45 \\
\hline 8. & Spatial orientation (concepts to the right, to the left, etc.) & 14 \\
\hline 9. & $\begin{array}{l}\text { Orientation in time (concepts yesterday, tomorrow, days of the } \\
\text { week, etc.) }\end{array}$ & 12 \\
\hline 10. & $\begin{array}{l}\text { Lack of language skills due to the child's origin (coming from an } \\
\text { immigrant family) }\end{array}$ \\
\hline
\end{tabular}

Educational institutions, where the surveyed teachers work, have support staff, who is involved in work with pupils at risk for dyslexia: all schools have a speech therapist (47 answers), a psychologist ( 8 answers) and a special pedagogue (6 answers) are involved in work as well.

Table 3 summarizes the answers to the question of teachers' further action when a pupil is likely to have reading disorders or dyslexia.

Table 3 Teachers' activity in cases of probability of reading disorders or dyslexia

\begin{tabular}{|l|l|c|}
\hline No. & \multicolumn{1}{|c|}{ Teacher's action } & $\begin{array}{c}\text { Number of } \\
\text { answers }\end{array}$ \\
\hline 1. & $\begin{array}{l}\text { Give him/her additional guidance during the implementation of various } \\
\text { activities }\end{array}$ & 8 \\
\hline 2. & Try to tailor activities to the child's needs & 18 \\
\hline 3. & $\begin{array}{l}\text { Collaborate with specialists (speech therapist, special pedagogue, } \\
\text { psychologist, attracted specialists) }\end{array}$ & 43 \\
\hline 4. & Help the child to communicate with peers & 5 \\
\hline 5. & Try to find out more about the problem and how you can help & 32 \\
\hline 6. & Cooperate closely with the child's parents & \\
\hline
\end{tabular}

\section{Conclusions}

1. The behaviour of primary school teachers in situations of reading disorders varies, but most of the correction work is done by a speech therapist.

2. It is important to carry out the professional development of primary school teachers by providing an understanding of the terms "reading disorders" and "dyslexia", knowledge of further action in the cases of reading disorders and dyslexia, support opportunities for pupils and parents, and opportunities for collaboration with a speech therapist.

3. It is necessary to develop a common methodological material for native language teachers for work with children with reading disorders or dyslexia in order to ensure that teachers, regardless of professional experience or knowledge, work as homogeneous as possible. 

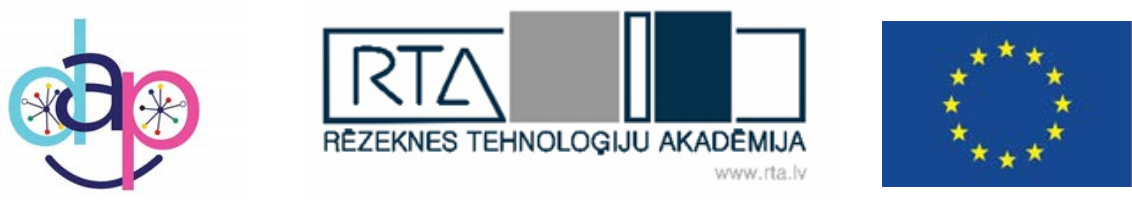

Lìdzfinansē

Eiropas Savienības

Erasmus+ programma

DAP: Dyslexia Assessment Protocol

Project No: 2019-1-LV01-KA201-060355

\section{References}

Alexander, P. \& Fox, E. (2004). A Historical Perspective on Reading Research and Practice. Theoretical Models and Processes of Reading. (5th ed.), 33-68.

Anspoka, Z. (2008). Latviešu valodas didaktika 1.-4.klasei. Rīga: RaKa.

Barquero, L.A., Davis, N., \& Cutting, L.E. (2014). Neurographic representation of reding reading intervention: systematic meta-analysis and assessment of the probability of activation.

Birzniece, E. (2019). Disleksija. Pieejams http://www.disleksija.lv/disleksija (skat. 21.01.2020.)

Buksa, F. (2016). Uzveikt disleksiju. Zvaigzne ABC.

Christo, C., Davis, N., \& Brock, S. (2009). Identifying, Assesing, and Treating Dyslexia at School. Springer.

Geske, A.\& Grīnfelds, A. (2001). Izglītības pētījumu metodologija un metodes. Rīga: IU RaKa.

Graff, H. (2008). Literacy Myths. In B. Street \& N. Hornberger (Eds.), Encyclopedia of Language and Education, No. 2, New York : Springer, 41-52.

Graham, Y. (2012). Dyslexia Tool Kit for Tutors and Parents: What to do when phonics isnt enough Create Space

Gurung, R.A.R. \& Schwartz, B.M. (2009). Optimizing Teaching and learning. United Kingdom: Wiley-Blackwell.

Hodge, P. (2000). A Dyslexic Child in the Classroom A Guide for Teachers and Parents.

Kauliña, A. \& Tūbele, S. (2012). Lasī̌šanas traucējumi. Izdevniecība: RaKa.

Kroplijs, A. \& Raščevska, M. (2004). Kvalitatīvo pētījumu metodes sociālajās zinātnēs. Rīga: Raka.

Marshall, A. (2005). Dyslexia Association International. Brain Function, Spell Reading, and Sweep-Sweep-Spellby Abigail Marshall.

Marshall, A. (2013). When Phonics Doesn't Work.

Marshall, A. (2019/a). When Dyslexics Become Good. DDAI.

Marshall, A. (2019/b). When Dyslexics Become Good Readers. Davis Dyslexia Assocation International.

Molfese,V, Molfese, D, Molnar, A, \& Beswick, J. (2010). Developmental dyslexia and dyslexia”. In Whitaker HA (ed.). A short encyclopedia of brains and language. Elsevier.

Nunes, T., Bryant, P. (2009). Childrens reading and spelling. Willey- Blackwell, A John Willey \& Sons Ltd. Publication, 296p.

Petrova, A. \& Ozola-Balode, Z. (2019). OECD pētījums: Latvijas skolēniem augstāki rezultāti matemātikā, zemāki - lasītprasmē. Pieejams: https://www.lsm.lv/raksts/zinas/latvija/ oecd-petijums-latvijas-skoleniem-augstaki-rezultati-matematika-zemaki-lasitprasme.a340439/ (skatīts 17.01.2019). 
Marite Rozenfelde et al.

Sprenger-Charolles, L. (2013). Reading acguisition and dyslexia in languages varying in orthographic depth: From behavior to bramin. Perspectives on Language and Literacy, 39, 23-32.

Torgesen, JK. (2005). Recent Discoveries on Remedial Interventions for Children with Dyslexia. In: Snowling MJ, Hulme C, editors. The science of reading: A handbook. Blackwell Publishing.

Tūbele, S. (2008). Disleksija vai lasī̌sanas traucējumi. RaKa.

Tūbele, S., Landra T., Šūmane, I., Burčaka, M., Laganovska, E., Kušnere, S., \& Vīgante, R. (2013). Metodiskais materiāls pedagogiem darbam ar izglītojamiem, kuriem ir mācīšanās traucējumi un redzes traucējumi. Rīga: VISC. 